DEPÓSITO LEGAL ZU2020000153

Esta publicación científica en formato digital

es continuidad de la revista impresa

ISSN 0041-8811

E-ISSN 2665-0428

Revista

de la

Universidad

del Tunlia

Fundada en 1947

por el Dr. Jesús Emrique Lossada

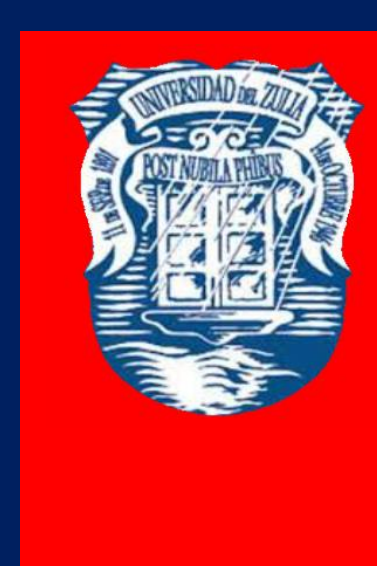

Ciencias

Sociales

y Arte

Aกัต 11 No 31

Septiembre - Diciembre 2021

Tercera ípoca

Maracailbo-Venezuela 


\title{
Functioning of food enterprises in the context of export development policies implementation
}

\author{
Marat Mirsayafovich Galeev * \\ Alexander Sergeevich Baleevskikh **
}

\begin{abstract} The article describes the development trends of the modern poultry product subcomplex as a raw material base for food industry and state export activity. Import substitution and increasing export volumes are a priority for the federal and regional development policies of Russia. In this regard, the aim of the study was to analyze the current state of food industry in the context of policy implementation of import substitution and export development. The achievement of the set goal was disclosed by solving several interrelated tasks: 1) analysis of resources of food products (eggs and egg products) and their use; 2) identification of a hidden correlation between indicators "production" and "import"; 3) identification of a hidden correlation between indicators "production" and "export". We hypothesized that indicators "production" and "export" of agri-food are directly correlated. Studies to identify hidden correlation dependencies have shown that there is a direct correlation between indicators "production" and "import". Indicators "production" and "export" don't have dependencies and influence on each other, therefore an increase in production doesn't affect the direct export of eggs from the country.
\end{abstract}

KEYWORDS: poultry farming, egg import, egg export, import substitution, food industry, economic conditions.

* Doctor of Economics, Professor of Department of Commodity Research and Examination of Goods, Perm State Agro-Technological University named after Academician D.N. Pryanishnikov, Russia. SPIN: 6097-2907. ORCID: https://orcid.org/0000-0001-7277-4644

**PhD in Economics, Head of Department of Commodity Research and Examination of Goods, Perm State Agro-Technological University named after Academician D.N. Pryanishnikov, Russia; PhD in Economics, Associate Professor of Department of Economics and Industrial Production Management, Perm National Research Polytechnic University, Russia. SPIN: 6097-2907. ORCID: https://orcid.org/0000-0002-6050-1275

Recibido: 08/05/2020

Aceptado: 10/07/2020 


\section{Funcionamiento de las empresas alimentarias en el contexto de la implementación de políticas para el desarrollo de exportaciones}

RESUMEN

El artículo describe las tendencias de desarrollo del subcomplejo moderno de productos avícolas como una base de materia prima para la industria alimentaria y la actividad de exportación estatal. La sustitución de importaciones y el aumento de los volúmenes de exportación son una prioridad para las políticas de desarrollo federales y regionales de Rusia. En este sentido, el objetivo del estudio fue analizar el estado actual de la industria alimentaria en el contexto de la implementación de políticas de sustitución de importaciones y desarrollo de exportaciones. El logro del objetivo establecido se reveló resolviendo varias tareas interrelacionadas: 1) análisis de recursos de productos alimenticios (huevos y productos de huevo) y su uso; 2) identificación de una correlación oculta entre los indicadores "producción" e "importación"; 3) identificación de una correlación oculta entre los indicadores "producción" y "exportación". Presumimos que los indicadores de "producción" y "exportación" de productos agroalimentarios están directamente correlacionados. Los estudios para identificar dependencias de correlación ocultas han demostrado que existe una correlación directa entre los indicadores "producción" e "importación". Los indicadores "producción" y "exportación" no tienen dependencias e influencia entre sí, por lo tanto, un aumento en la producción no afecta la exportación directa de huevos desde el país.

PALABRAS CLAVE: avicultura, importación de huevos, exportación de huevos, sustitución de importaciones, industria alimentaria, condiciones económicas.

Introduction

In the history of economic development of modern Russia, 2014 was a turning point. Political events of this time, which occurred in connection with Crimean referendum, caused the adoption of a number of developed states in relation to the Russian Federation of action measures of an economic nature. The negative foreign economic situation resulted in supply blockade of imported food to Russia. This was a decisive but well-considered step by the Russian Government, the results of which were manifested in the opening of domestic food markets for domestic producers.

It should be objectively noted that the Russian market for agricultural goods and food was increasingly dependent on their supplies from external sources before sanctions. Despite 
REVISTA DE LA UNIVERSIDAD DEL ZULIA. 3e época. Año $11 \mathrm{~N}^{\circ}$ 31, 2020

Marat Mirsayafovich Galeev \& Alexander S. Baleevskikh /// Functioning of food enterprises ...119-130

DOI: http://dx.doi.org/10.46925//rdluz.31.09

the entry of the Russian Federation into the World Trade Organization, whose domestic policy should be based on the mutual parity of export-import operations, Russia was in the conditions of acquiring country. N. A. Kudrova notes that this dependence was removed and the domestic agro-industrial complex received a new growth impulse (Kudrova, 2015). Understanding the importance of food security and opportunity to build up export potential, the country's leadership took a number of significant measures of state support to domestic agricultural sector (Arbeláez-Campillo and Rojas-Bahamón, 2020).

The increase in efficiency of domestic farmers' access to international markets was reflected in the Address of the President of the Russian Federation to the Federal Assembly on 02.20.2019 (The List of instructions for implementation of the President's Address to the Federal Assembly, 2019). Earlier, the Government of the country in order to support commodity export of the agro-industrial complex developed and adopted the priority project "Export of agricultural products". This project was based on requirements of the first person of the state on the development of strategic development of the country, including export of food products and agricultural products, bringing the sales revenue to $\$ 45$ billion by 2024 (The List of instructions for implementation of the President's Address to the Federal Assembly, 2019).

The relevance of the topic of the article is not in doubt and is due to decrees of the first persons of the country. In our opinion, domestic food enterprises should be considered from two sides: firstly, the appropriateness of export support in general, and secondly, the ways and methods of such support and possibility of improving it.

Based on above justification of research topic relevance, we set the following goal: to analyze the current state of food industry in the context of import substitution policy implementation and export development.

\section{Materials and methods}

The goal was disclosed by solving several interrelated tasks:

1) to analyze the resources of food products on the example of eggs and egg products and their use;

2) to reveal hidden correlation dependencies between the indicators "production" and "import"; 
REVISTA DE LA UNIVERSIDAD DEL ZULIA. 3e época. Año $11 \mathrm{~N}^{\circ}$ 31, 2020

Marat Mirsayafovich Galeev \& Alexander S. Baleevskikh /// Functioning of food enterprises ...119-130

DOI: http://dx.doi.org/10.46925//rdluz.31.09

3) to reveal hidden correlation dependencies between the indicators "production" and "export".

The tasks were solved by the following scientific methods: abstract-logical, balance, analysis and synthesis, sensory and monographic.

The scientific hypothesis of this article was the authors' assumption that the indicators "production" and "export" of agri-food are directly correlated.

The statistics of the Ministry of Agriculture and the Federal Customs Service served as an information base for research.

\section{Results}

To solve the first problem, namely, the analysis of resources of food products using the example of eggs and egg products, we examined the ratio of production, export and import of agricultural products. The intensification of the Russian economy's entry into foreign markets, including the agricultural food sector, is at its initial stage. According to V. A.Semykin, V. V. Safronov, V. P. Terekhov, an assessment of Russia's economic development over the past 10 years confirms a significant increase in imports of products with a wide range of applications (Semykin et al, 2014). However, with the introduction of sanctions and retaliatory measures from the Russian Federation of an economic nature, starting in 2015, a decrease in the share of imports relative to the country's GDP has been observed. This was made possible largely due to market niches that opened up for domestic producers in view of the reduction in imports of goods caused by political decisions. At the same time, researchers M. M. Galeev, E. M. Radosteva, E. V. Bartova, G. N. Ivanova note that the raw materials economy of Russia is poorly focused on production of consumer goods, including a number of fruits and vegetables, meat and dairy products (Galeev et al, 2015; Ivanova, 2011). The need for them is met through imports. So, A. S. Baleevskikh states that according to the results of the period from 2015 to 2018 the dynamics of foreign trade import operations grew, respectively, from 184500 to 233400 million US dollars (Baleevskikh, 2018).

The presented indicators confirm the current belief that in the context of globalization, Russia will not be able to avoid import dependence on many types of innovative products and components for its production completely. However, as part of national economic strategy implementation, it is necessary to ensure self-sufficiency and independence of economy key sectors from external factors (Supporting Investment in 
REVISTA DE LA UNIVERSIDAD DEL ZULIA. 3e época. Año $11 \mathrm{~N}^{\circ}$ 31, 2020

Marat Mirsayafovich Galeev \& Alexander S. Baleevskikh /// Functioning of food enterprises ...119-130

DOI: http://dx.doi.org/10.46925//rdluz.31.09

Knowledge Capital, Growth and Innovation, 2013). We have to agree with Yu. V. Vertakova, V. A. Plotnikov, V. V. Ivanov, who believe that today a strategy aimed at restructuring the economic development model by switching import-substituting production and technologies in strategically important sectors is crucial for Russia (Vertakova, Plotnokov, 2013; Ivanov, 2015).

These sectors, first of all, include agriculture and the food industry, since over the years a stable structure of food imports has formed. The leading positions here are occupied by meat (mainly cattle) - 15-16\%, fruits - 14.8, vegetables - 6.7, dairy products - 10 and $8 \%$ alcohol products (The Official website of the Federal Customs Service of Russia, 2020).

The probability of import dependence for a number of food products for the Russian Federation remains high and, practically, constant over time. These include tropical and subtropical fruits, nuts and spices. Along with this, there are vital food products which production in Russia is industrial in nature. These include chicken eggs and their processed products. In this regard, we conducted a correlation analysis aimed at identifying the presence or absence of relationship between the production of poultry products by their imports and exports. We also calculated indicators of self-sufficiency, import substitution and import dependence. The calculation of the required data was performed using the following mathematical apparatus:

a) self-sufficiency-

$$
\alpha=\frac{P-E}{P+I-E} \cdot 100 \%, \text { where }
$$

$\mathrm{P}$ - domestic products;

E- export;

I - import.

b) import substitution for the period $t-$

$$
\Delta_{t}=\alpha_{t}-\alpha_{0}
$$

c) import dependence -

$$
\gamma=\frac{I}{P+I-E} \cdot 100 \%
$$

Note that the indicators of self-sufficiency $(\alpha)$ and import dependence $(\gamma)$ are complementary:

$$
\alpha+\gamma=100
$$


REVISTA DE LA UNIVERSIDAD DEL ZULIA. 3e época. Año $11 \mathrm{~N}^{\circ}$ 31, 2020 Marat Mirsayafovich Galeev \& Alexander S. Baleevskikh /// Functioning of food enterprises ...119-130 DOI: http://dx.doi.org/10.46925//rdluz.31.09

An analysis of the dynamic range of availability of poultry production resources and their use will underlie the determination of required indicators of self-sufficiency, import substitution and import dependence in the form of their coefficients. The dynamics of resource potential of eggs in the Russian Federation for the period 2006-2018 is shown in Table 1.

Table 1. The dynamics of eggs potential resources in the Russian Federation, million pieces

\begin{tabular}{|c|c|c|c|c|c|c|c|c|c|c|c|c|c|}
\hline \multirow{2}{*}{ Indicators } & \multicolumn{13}{|c|}{ Years } \\
\hline & 2006 & 2007 & 2008 & 2009 & 2010 & 2011 & 2012 & 2013 & 2014 & 2015 & 2016 & 2017 & 2018 \\
\hline \multicolumn{14}{|c|}{ I. Resources } \\
\hline $\begin{array}{l}\text { Stocks at the beginning of } \\
\text { the year }\end{array}$ & 980 & 1061,9 & 958,8 & 1080,3 & 1081,8 & 1024,1 & 1115,7 & 1169,3 & 1146,1 & 1054,0 & 1146,4 & 1316,9 & 1285,7 \\
\hline Production & 38108 & $\begin{array}{r}38 \\
161,7 \\
\end{array}$ & $\begin{array}{r}38 \\
077,4 \\
\end{array}$ & $\begin{array}{r}39 \\
468,4 \\
\end{array}$ & $\begin{array}{r}40 \\
759,2 \\
\end{array}$ & $\begin{array}{r}41 \\
288,9 \\
\end{array}$ & $\begin{array}{r}42 \\
132,7 \\
\end{array}$ & $\begin{array}{r}41 \\
390,2 \\
\end{array}$ & $\begin{array}{r}41 \\
747,1 \\
\end{array}$ & $\begin{array}{r}42 \\
509,5 \\
\end{array}$ & $\begin{array}{r}43 \\
514,5 \\
\end{array}$ & $\begin{array}{r}44 \\
829,1 \\
\end{array}$ & $\begin{array}{r}44 \\
900,9 \\
\end{array}$ \\
\hline Import & 900 & 863,4 & 833,1 & 793,5 & 881,3 & 1169,6 & 1345,1 & 1212,3 & 1241,7 & 1241,2 & 1241,1 & 1206,4 & 1255,9 \\
\hline Total resources & 39988 & $\begin{array}{r}40 \\
087,0 \\
\end{array}$ & \begin{tabular}{|r|}
39 \\
869,3 \\
\end{tabular} & $\begin{array}{r}41 \\
342,2 \\
\end{array}$ & $\begin{array}{r}42 \\
722,3 \\
\end{array}$ & \begin{tabular}{|r|}
43 \\
482,6 \\
\end{tabular} & $\begin{array}{r}44 \\
593,5 \\
\end{array}$ & $\begin{array}{r}43 \\
771,8 \\
\end{array}$ & \begin{tabular}{|r|r|}
44 \\
134,9 \\
\end{tabular} & $\begin{array}{r}44 \\
804,7 \\
\end{array}$ & $\begin{array}{r}45 \\
902,0 \\
\end{array}$ & $\begin{array}{r}47 \\
352,4 \\
\end{array}$ & $\begin{array}{r}47 \\
442,5 \\
\end{array}$ \\
\hline \multicolumn{14}{|c|}{ II. Use } \\
\hline Production consumption & 2107 & 2252,0 & 2362,6 & 2706,9 & 2853,4 & 3079,7 & 3323,7 & 3469,8 & 3661,5 & 3908,9 & 4077,1 & 4273,6 & 4173,7 \\
\hline Losses & 59 & 77,0 & 67,6 & 66,2 & 102,7 & 99,3 & 90,9 & 87,1 & 72,6 & 86,2 & 79,0 & 110,1 & 92,9 \\
\hline Export & 395 & 411,8 & 284,6 & 300,4 & 243,6 & 278,2 & 417,5 & 400,3 & 304,7 & 353,8 & 451,7 & 720,3 & 769,8 \\
\hline Personal consumption & 36369 & $\begin{array}{r}36 \\
387,4 \\
\end{array}$ & $\begin{array}{r}36 \\
074,2 \\
\end{array}$ & $\begin{array}{r}37 \\
186,9 \\
\end{array}$ & $\begin{array}{r}38 \\
498,5 \\
\end{array}$ & $\begin{array}{r}38 \\
909,7 \\
\end{array}$ & $\begin{array}{r}39 \\
592,1 \\
\end{array}$ & $\begin{array}{r}38 \\
675,9 \\
\end{array}$ & $\begin{array}{r}39 \\
042,1 \\
\end{array}$ & $\begin{array}{r}39 \\
309,4 \\
\end{array}$ & $\begin{array}{r}39 \\
977,3 \\
\end{array}$ & $\begin{array}{r}40 \\
962,7 \\
\end{array}$ & $\begin{array}{r}41 \\
169,4 \\
\end{array}$ \\
\hline $\begin{array}{l}\text { Reserves at the end of the } \\
\text { reporting period }\end{array}$ & 1058 & 958,8 & 1080,3 & 1081,8 & 1024,1 & 1115,7 & 1169,3 & 1138,7 & 1054,0 & 1146,4 & 1316,9 & 1285,7 & 1236,7 \\
\hline \multicolumn{14}{|c|}{ III. Indicators } \\
\hline \multicolumn{14}{|l|}{ Odds: } \\
\hline Self sufficiency & 0,9767 & 7) 0,9776 & 0,9784 & 0,9801 & 0,9787 & 0,9723 & 0,9688 & 0,9713 & 0,9709 & 0,9714 & 0,9720 & 0,9734 & 0,9723 \\
\hline Import substitution & & 0,0009 & 0,0017 & 0,0034 & 0,0020 & 0,0044 & 0,0079 & 0,0054 & 0,0058 & 0,0053 & 0,0047 & 0,0033 & 0,0044 \\
\hline Import dependence & 0,0233 & 0,0224 & 0,0216 & 0,0199 & 0,0213 & 0,0277 & 0,0312 & 0,0287 & 0,0291 & 0,0286 & 0,0280 & 0,0266 & 0,0277 \\
\hline
\end{tabular}

The table is compiled by the authors based on materials from the Federal Customs Service of the Russian Federation (The Official Website of the Federal Customs Service of Russia, 2020).

The materials in Table 1 show that, starting in 2006, egg production in the country increased by 6792.9 million, or $17.8 \%$. The increased share of imports should be noted. Over 13 years, it has grown by $39.9 \%$. This allowed to increase the resource base of chicken eggs in 
REVISTA DE LA UNIVERSIDAD DEL ZULIA. 3e época. Año $11 \mathrm{~N}^{\circ}$ 31, 2020

Marat Mirsayafovich Galeev \& Alexander S. Baleevskikh /// Functioning of food enterprises ...119-130

DOI: http://dx.doi.org/10.46925//rdluz.31.09

the country by $18.6 \%$ by 2018 . As a result, there was an increase in egg consumption within the state by $13.2 \%$.

Positive production dynamics had a favorable effect on such an indicator as the coefficient of self-sufficiency. Over the years under review, its level was almost stable and equal to 0.97 , which indicates a high degree of domestic production of chicken eggs in the Russian Federation.

International trade relations of various countries, in the conditions of stable political relations, as a rule, are based on the principles of market openness. Therefore, the desire of one side to carry out only export operations inevitably runs into a similar desire of the opposite side. Trade relations of Russia are no exception. Along with the export of goods, it is compelled (even with its own self-sufficiency) to use import products. In this regard, we note that our import dependence over the years ranges from 2 to 3\% (Table 1).

To identify the hidden correlation between the indicators "production" and "import", we used the mathematical apparatus, investigated the dependence of the indicators "production" and "import". To obtain a more accurate assessment of correlation relationships, it was decided to use the statistical control tool "Scatter Diagram", which includes the median method. Figure 1 , taking into account the data in Table 1 , reflects the first pair of dependencies - production and import of eggs.

The horizontal and vertical medians drawn in Figure 1 divide the scatter diagram into four quarters, each of which contains or completely lacks points that reflect the absolute values of the "import" indicator.

The sum of even and odd quarters of the considered time periods is expressed in the following indicators:

$$
\begin{aligned}
& \mathrm{n}_{(+)}=\mathrm{n}_{1}+\mathrm{n}_{3}=6+6=12, \\
& \mathrm{n}_{(-)}=\mathrm{n}_{2}+\mathrm{n}_{4}=0+0=0, \\
& \mathrm{n}^{\prime}=\mathrm{n}_{(+)}+\mathrm{n}_{(-)}=12+0=12 .
\end{aligned}
$$

It is noted that one point is at the intersection of medians, so $n{ }^{\prime}=12$ is not equal to $n=$ 13.

To establish the tightness of the correlation dependence, we set the risk coefficient $\alpha$ $=0.05$ and determine the code value.

The median method assumes that in order to confirm the relationship between a pair 
REVISTA DE LA UNIVERSIDAD DEL ZULIA. 3e época. Año $11 \mathrm{~N}^{\circ}$ 31, 2020 Marat Mirsayafovich Galeev \& Alexander S. Baleevskikh /// Functioning of food enterprises ...119-130 DOI: http://dx.doi.org/10.46925//rdluz.31.09

of presented indicators, it is necessary that an inequality is satisfied in which the smaller of the numbers $\mathrm{n}(+)$ and $\mathrm{n}(-)$ is less than $\left(\iota^{)}\right.$or equal $(=)$to the code value, which is 2 according to the Table 2.

Table 2. The dependence of the code value on the risk coefficient and the number of points that didn't fall on the medians

$\begin{array}{clcccccccccccccccccc} & \mathrm{n} & 8 & 9 & 10 & 11 & 12 & 13 & 14 & 15 & 16 & 17 & 18 & 19 & 20 & 21 & 22 & 23 & 24 & 25 \\ \alpha & 0.01 & 0 & 0 & 0 & 0 & 1 & 1 & 1 & 2 & 2 & 2 & 3 & 3 & 3 & 4 & 4 & 4 & 5 & 5 \\ & 0.05 & 0 & 1 & 1 & 1 & 2 & 2 & 2 & 3 & 3 & 4 & 4 & 4 & 5 & 5 & 5 & 6 & 6 & 7\end{array}$

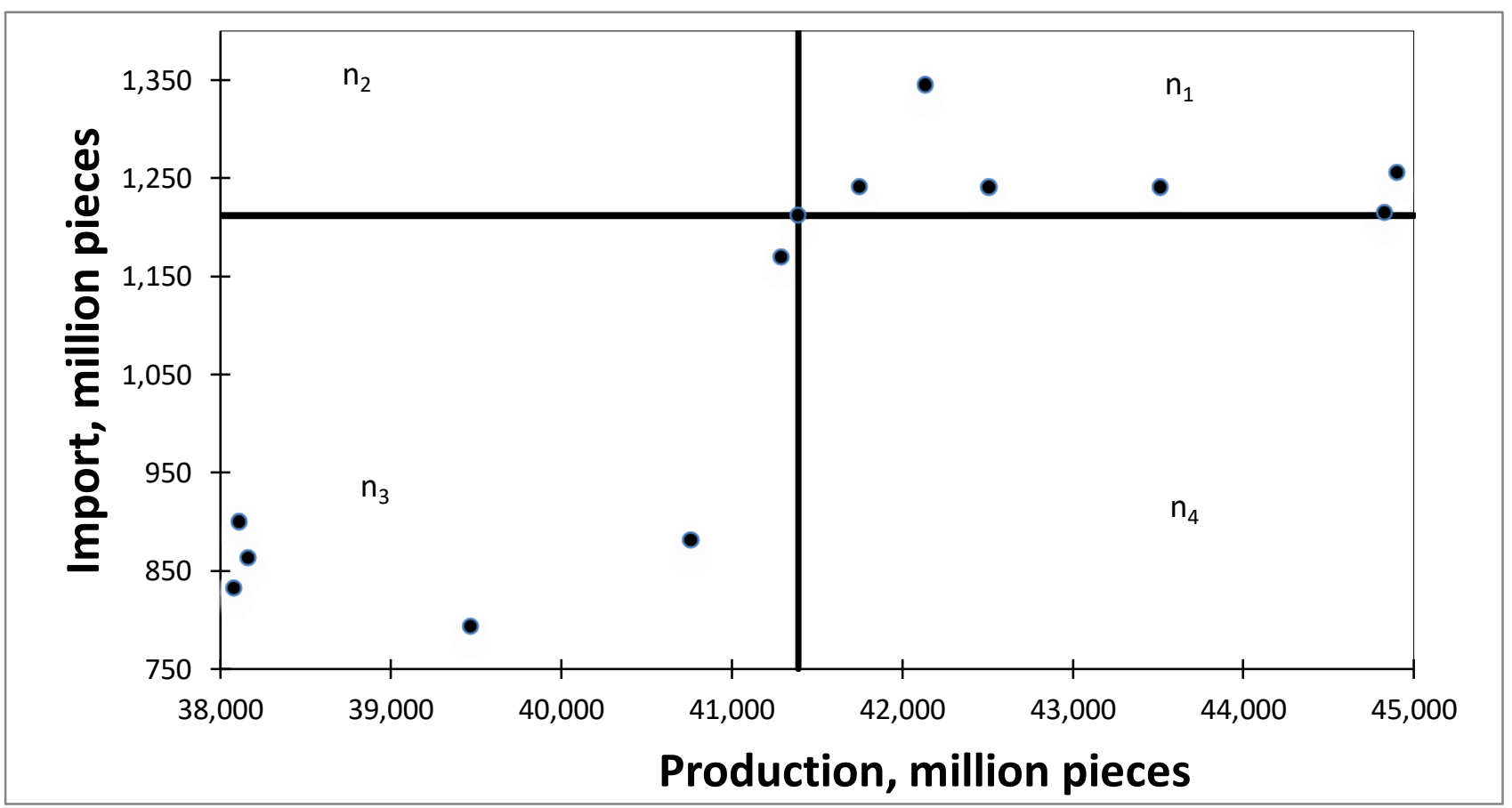

Figure 1. Scatter chart (median method), reflecting the dependence of production and import of eggs using statistical Table 2.

Further analysis allows us to draw the following conclusion. Smaller number $\mathrm{n}_{(-)}=0$, that is $\leq 2$. This means that with a risk factor of 0.05 , there is indeed a direct correlation. The validity of this conclusion is $95 \%$. It confirms the dependence of the import of eggs on their own production. An increase in the coefficient of self-sufficiency will decrease the indicator of import dependence.

To solve the third problem and test the hypothesis of the existence of a direct 
REVISTA DE LA UNIVERSIDAD DEL ZULIA. 3e época. Año $11 \mathrm{~N}^{\circ}$ 31, 2020 Marat Mirsayafovich Galeev \& Alexander S. Baleevskikh /// Functioning of food enterprises ...119-130 DOI: http://dx.doi.org/10.46925//rdluz.31.09

correlation between a pair of indicators "production" and "export" of eggs, we prepared the corresponding "scatter diagram" (Figure 2).

The scatter chart reflected in Figure 2 shows the number of points in each quarter corresponding to the "export" indicator in each sequential (time) period:

$$
\begin{aligned}
& \mathrm{n}_{(+)}=\mathrm{n}_{1}+\mathrm{n}_{3}=4+4=8, \\
& \mathrm{n}_{(-)}=\mathrm{n}_{2}+\mathrm{n}_{4}=1+2=3, \\
& \mathrm{n}^{\prime}=\mathrm{n}_{(+)}+\mathrm{n}_{(-)}=8+3=11 .
\end{aligned}
$$

Two points that fall on the medians aren't taken into account, therefore $n^{\prime}=11$, not $n=13$.

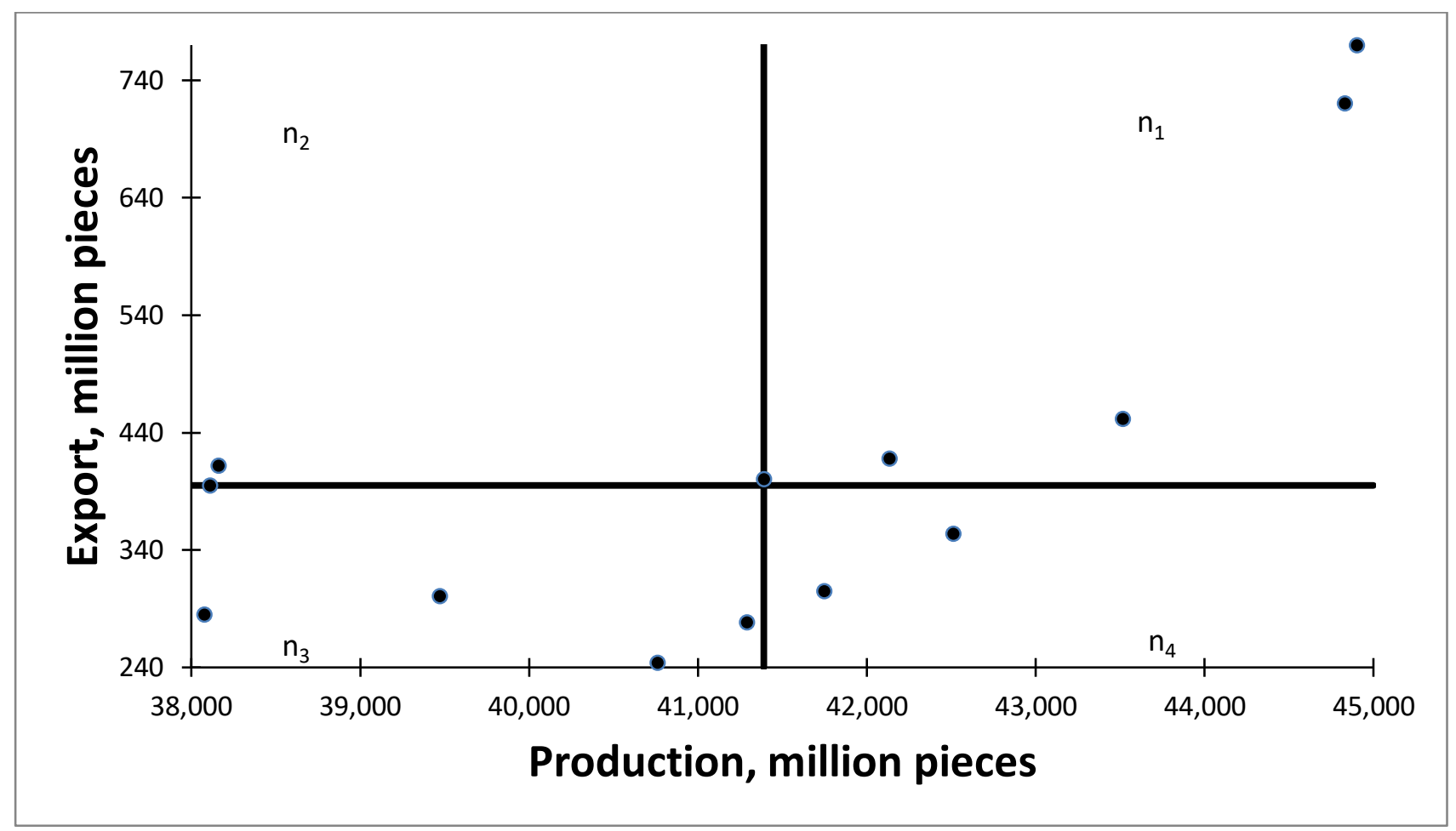

Figure 1. Scatter chart (median method), reflecting the dependence of production and export of eggs

The code value for the risk coefficient $\alpha=0.05$, based on statistical Table 2 , is 1 . According to the methodology, the smaller of the numbers $\mathrm{n}(+)$ and $\mathrm{n}(-)$ must be $\leq$ a code value. However, $\mathrm{n}_{(-)}=3$ is greater than a code value of 1 . This means that with a risk factor of 0.05 , there is no direct correlation between the indicators "production" and "export", with a probability of $95 \%$. Thus, an increase and decrease in domestic production does not affect the number of eggs exported. 
REVISTA DE LA UNIVERSIDAD DEL ZULIA. 3e época. Año $11 \mathrm{~N}^{\circ}$ 31, 2020

Marat Mirsayafovich Galeev \& Alexander S. Baleevskikh /// Functioning of food enterprises ...119-130

DOI: http://dx.doi.org/10.46925//rdluz.31.09

\section{Discussion}

A large number of scientists, such as N. M. Binti Abdul Manap, consider Russia one of the largest exporters of food products and emphasize the country's importance in world trade (Binti Abdul Manap, 2019). Our calculations showed that the country has so far failed to increase the share of world egg trade.

The problem of increasing the export of agricultural products deserves special attention. A number of modern scholars believe that with the growth in the export of raw food products, the food security of Russia is strengthening. V. Daskovsky and V. Kiselev regard the export of commodities as a mistake in economic policy. They argue: "Huge losses on the import of expensive livestock products do not cover the income from the export of raw materials" (Daskovsky, Kiselev, 2018).

Experts of the Center for Statistical Research A. N. Spartak, A. Yu. Knobel, T. A. Flegontova believe that in 2024, Russian food exports should reach $\$ 50$ billion (Spartak et al, 2018). However, more conservative forecasts are presented by A. Petrikov and V. Morozov, who believe that the planned export volume in 2020 will amount to 21.4 billion dollars and in 2030 only 30.0 billion dollars (Petrikov, 2017; Morozov, 2018).

Academician of the Russian Academy of Sciences, President of the Russian Federal Agency for Veterinary and Phytogenesis, V. I. Fisinin, makes the following forecast for the development of Russian egg exports: "According to forecasts, the export potential of Russian poultry farming for the future can be identified by the following indicators: food eggs in 2020 - 850-900 million; in 2025 - more than 1 billion units "(Fisinin, 2017). A. A. Efremova, chief specialist of the Federal State Budgetary Institution "Analytical Center of the Ministry of Agriculture of Russia" believes that "the share of Russia in the world export of food eggs has grown in recent years, but the geography of supplies is still limited: Ukraine (28\%), Mongolia (28\%), Tajikistan (20\%), UAE (12\%) due to significantly low price and high quality" (Efremova, 2018).

\section{Conclusions}

1. The studies carried out allow us to conclude that the actively changing foreign policy and the statements of the top officials of the country put the problem of import substitution in the food industry to the fore. At present, high growth rates of imports continue to be 
REVISTA DE LA UNIVERSIDAD DEL ZULIA. 3e época. Año $11 \mathrm{~N}^{\circ}$ 31, 2020

Marat Mirsayafovich Galeev \& Alexander S. Baleevskikh /// Functioning of food enterprises ...119-130

DOI: http://dx.doi.org/10.46925//rdluz.31.09

observed. At the same time, a significant increase in import of products was recorded in agricultural and food sectors of the economy.

We have performed research on the current state and dynamics of development indicators of the poultry industry in the Russian Federation. The results indicate that at the end of 2018, the egg self-sufficiency indicator is 0.97 , therefore, the level of self-sufficiency corresponds to a high degree of satisfaction of the need for egg products due to own production.

2. For this industry, we conducted an additional study of the relationship between the indicators "production" and "import". As a result, it was revealed that there is a direct correlation between these indicators. An increase or decrease in domestic production directly affects the number of eggs imported.

3. A study of indicators "production" and "export" showed that there is no correlation between them. The number of eggs exported doesn't depend on the volume of own production, but is influenced by other factors. The hypothesis put forward by us was refuted, although at first glance it would be logical to solve the problem of increasing the export of poultry production by expanding production capacities. The continuation of these studies may be the analysis and assessment of factors affecting the export of domestic eggs and egg products.

In general, state support remains the most important condition for increasing competitiveness and reducing the import dependence of the food industry in Russia.

\section{References}

Arbeláez-Campillo, D. F.; Rojas Bahamón, M.J. (2020). Visión y revisión de artículos científicos sobre temática agrícola en la revista Amazonía Investiga // Revista de la Universidad del Zulia, 11 (29), 285-306. DOI: http://dx.doi.org/10.46925//rdluz.29.19

Baleevskikh, A. S. (2018). Implementation of the state subprogram for the development of exports, agricultural products // Far Eastern Agrarian Bulletin. No. 4 (48). P. 290-296.

Binti Abdul Manap, N. M. (2020). Food security and economy growth in developing countries. Available at: http://psasir.upm.edu.my/id/eprint

Daskovsky, V., Kiselev, V. (2018). On the strategy of economic security and socio-economic development // Economist. No. 3. P. 24-44.

Efremova, A. A. (2018). Analysis of world exports and imports of food eggs // Risk Management 
REVISTA DE LA UNIVERSIDAD DEL ZULIA. 3e época. Año $11 \mathrm{~N}^{\circ}$ 31, 2020 Marat Mirsayafovich Galeev \& Alexander S. Baleevskikh /// Functioning of food enterprises ...119-130

DOI: http://dx.doi.org/10.46925//rdluz.31.09

in the AIC. No. 4. P. 62-69. Available at: http://www.agrorisk.ru/20180404

Fisinin, V. I. (2017). Export potential of poultry products in Russia: past, present, future // Poultry farming. No. 10. P. 5-10.

Galeev, M. M., Radosteva, E. M., Bartova, E. V. (2015). Possibilities of import substitution in the food security system of Russia // Internet journal «Science Studies». No. 3 (28). Available at: https://naukovedenie.ru/

Ivanov, V.V. (2015). Conceptual foundations of a national technological initiative // Innovations. No. 1. P. 8-14.

Ivanova, G. N. (2011). International Standards Against an Unstable Economy // Standards and Quality. No.11. P. 72-74.

Kudrova, N. A. (2015). Stimulating policy of regional development of modern Russia on the basis of the concept of import substitution // Socio-economic phenomena and processes. V. 10. No. 2. P. 46-5l.

Morozov, V. (2018). Foreign trade problems of the development of the agro-industrial complex of the Russian Federation // Russian Foreign Economic Bulletin. No. 3. P. 75-81.

Petrikov, A. (2017). Development of export of Russian agricultural products: problems and solutions // Export potential of the Russian agricultural sector: state and prospects. M.: VIAPI named after A. A. Nikonova. P. 443.

Semykin, V. A., Safronov, V. V., Terekhov, V. P. (2014). Import substitution as an effective tool for the optimal development of a market economy // Bulletin of the Kursk State Agricultural Academy. No.7. P. 2-7.

Spartak, A. N., Knobel, A.Yu.,Flegontova, T. A. (2018). Prospects for increasing Russian nonresource exports. M.: Center for Statistical Development.

Speech by Putin V. V. At the plenary meeting of the 18th St. Petersburg International Economic Forum (2020). Available at: http://www.kremlin.ru.

Supporting Investment in Knowledge Capital, Growth and Innovation (2013). OECD: OECD publishing.

The doctrine of food security of the Russian Federation. Approved by presidential decree No. 120 of 30.04. 2010. (2020). Available at: https://rg.ru/

The list of instructions for the implementation of the Presidential Address to the Federal Assembly (2020). Available at: http://base.garant.ru/12172719/\#friends.

The official website of the Federal Customs Service of Russia (2020). Available at: http://www.customs.ru Vertakova, Yu. V., Plotnikov, V.A. (2014). Import substitution: theoretical foundations and prospects for implementation in Russia // Economics and Management. No. 11. P. 11-47. 